\title{
ASSESSMENT AND COMPARISON OF THE CARIOGENICITY OF THE GIRLS AND BOYS DIET IN THE SELECTED GROUP OF YOUNG PEOPLE AGED 15-16 YEARS OLD
}

\section{OCENA I PORÓWNANIE KARIOGENNOŚCI DIETY DZIEWCZĄT I CHŁOPCÓW W WIEKU 15-16 LAT}

Department of Human Nutrition Physiology, West Pomeranian University

of Technology, Szczecin, Poland

\begin{abstract}
Streszczenie. Prawidłowe nawyki żywieniowe mają istotny wpływ na stan zdrowia człowieka, w tym na stan zębów i przyzębia, a popełniane błędy żywieniowe odzwierciedlają się we wzroście częstości występowania chorób, takich jak próchnica, paradontoza, kwasowa erozja szkliwa, stany zapalne przyzębia. Celem badań była ocena kariogenności diety wybranej grupy młodzieży w wieku 15-16 lat. Badania przeprowadzono w czerwcu 2016 roku w szczecińskich gimnazjach. Wzięło w nich udział 251 osób (115 chłopców i 136 dziewcząt). Badanie polegało na wypełnieniu anonimowej ankiety dotyczącej zwyczajów żywieniowych wpływających na kariogenność diety. Uzyskane wyniki badań wskazują na częste występowanie zachowań i wyborów żywieniowych, które sprzyjają rozwojowi próchnicy zębów. Należały do nich: brak regularności w spożywaniu posiłków, które deklarowało $73 \%$ badanych, częste pojadanie między posiłkami (deklarowane przez 97,1\% dziewcząt i 99,1\% chłopców), częste jedzenie słodyczy i produktów słodzonych oraz picie słodkich napojów. Dziewczęta charakteryzowały się mniej poprawnymi zachowaniami żywieniowymi niż chłopcy, rzadziej jadały zalecaną ilość posiłków, odżywiały się mniej regularnie, wypijały mniej płynów, natomiast chłopcy dokonywali gorszych wyborów żywieniowych: rzadziej, niż dziewczęta, jadali razowe pieczywo, częściej wybierali słodkie płatki zbożowe, słodkie jogurty i kefiry oraz częściej pili słodkie napoje. Biorąc pod uwagę stwierdzone nieprawidłowości, polegające na znacznej liczbie błędów żywieniowych wpływających na wzrost kariogenności diety, młodzież w wieku szkolnym powinna szczególnie starannie dbać o higienę jamy ustnej i brać udział w edukacji żywieniowej. A stomatolodzy powinni zwracać uwagę na znaczenie zasad prawidłowego żywienia w profilaktyce przeciwpróchnicowej i ukierunkowanie pacjentów na korektę zachowań, które sprzyjają chorobom zębów i przyzębia.
\end{abstract}

Key words: caries-forming diet, nutritional behavior, state of dentition, middle school students.

Słowa kluczowe: dieta próchnicotwórcza, zachowania żywieniowe, stan uzębienia, młodzież gimnazjalna.

\section{INTRODUCTION}

The genetic, environmental as well as social and economic conditions have impact on the development and its correct dentition. The role of nutrition is included in the environmental factors. The correct dietary habits have a significant impact on human health in general,

Corresponding author - Adres do korespondencji: Joanna Sadowska, Department of Human Nutrition Physiology, West Pomeranian University of Technology, Szczecin, Papieża Pawła VI 3, 71-459 Szczecin, Poland, e-mail: joanna.sadowska@zut.edu.pl 
including dental and periodontal health, and nutrition mistakes made by people are reflected in increasing occurrence of dental diseases such as: dental decay, periodontosis, acid enamel erosion or periodontal inflammation (Moynihan and Petersen 2004). The diet contributing to dental decay is called cariogenic.

Dental caries occurs due to demineralisation and proteolytic decay of dentine (the hard tissue of the teeth). It is mainly caused by incorrect oral care and bad dietary habits (Bagińska and Stokowska 2006). Streptococcus multans and Streptococcus sobrinus, the bacteria with cariogenic potential, play a crucial role in the process, they are transmitted to the mouth of babies aged 19-31 months or children aged 6 to 12 years when deciduous dentition is replaced by the permanent one (Law et al. 2007; Vacca Smith et al. 2007). The deciduous teeth and adolescent permanent dentition are particularly susceptible to dental caries, therefore increased susceptibility to dental caries lasts from the first eruption of tooth until the age of 15-16 years.

The incidence of dental caries in Polish children is higher comparing to their peers from Western or Southern Europe (Ganowicz et al. 2007). Average occurrence of dental caries in Poland is at $91.8 \%$, Hilt et al. (2014) observed dental caries in $93.8 \%$ of surveyed middle school students in the Łódź region and Turska-Szybka et al. (2016) reported dental caries in $94.5 \%$ of middle school students surveyed in the Mazowsze region. The incidence of tooth decay increases with age and in the eighteen-year-old youth is $96.1 \%$, covering an average of 8 teeth (Strużycka et al. 2013).

Following healthy eating habits such as: eating regular meals, eliminating snacks between meals, avoiding too frequent exposure of mucosa in the mouth and teeth to sucrose derived from sweets, adding sugar to meals or eating added sugar hidden in foodstuffs, is a key factor in preventing caries. Therefore, not only occurring sucrose in the diet is of key importance but also its frequency of consumption or its form (liquid or solid), food texture (hardness, viscosity), the order in which food with high and low cariogenic potential is eaten and type of fluid intake, including frequency of consuming sweetened drinks such as sugared tea, fruit juices, fruit drinks and Coke-like drinks (Moynihan and Petersen 2004; Olczak-Kowalczyk et al. 2015).

The survey carried out to assess the nutrition of children and young people at the school age showed that their diet does not comply with the principles for good nutrition, however, there are only few attempts to assess diet composition and dietary habits in the context of their impact on the health of dentition and periodontium.

The survey objective was to assess the cariogenicity of diet in selected group of young people aged $15-16$ years old.

\section{MATERIAL AND METHODS}

The survey was conducted in June 2016 among young people aged 15-16 attending middle schools in Szczecin (Poland). A group of 251 young people, including 115 boys and 136 girls, took part in the survey that was voluntary and based on an anonymous dietary questionnaire on eating habits affecting cariogenicity of diet, determining the frequency of consuming cariogenic and cariostatic foodstuffs as well as conducting anthropometric 
measurements (weight and height). $85.3 \%$ of respondents took part in the anthropometric measurements. The assessment of the nutritional status of the surveyed youth was made on the basis of the value of the BMl index (calculated from the formula: BMl = body weight $[\mathrm{kg}] /$ body height $[\mathrm{m}]^{2}$ ), which was interpreted on the basis on updated growth charts in which BMI cut-off points are shown for underweight, normal body weight and overweight in particular age groups of girls and boys (Różdżyńska-Świątkowska et al. 2013). The analysis of respondents' nourishment is shown in Table 1.

Table 1. Anthropometric characteristics of surveyed youth Tabela 1. Charakterystyka antropometryczna badanej młodzieży

\begin{tabular}{lccc}
\hline \multicolumn{1}{c}{ Trait - Cecha } & Boys - Chłopcy & Girls - Dziewczęta & Total - Razem \\
\hline Body weight - Masa ciała [kg] & $66.4 \pm 11.6$ & $56.9 \pm 9.2$ & $61.4 \pm 11.4$ \\
\hline Body height - Wzrost [cm] & $175.8 \pm 6.6$ & $164.1 \pm 5.8$ & $169.7 \pm 8.5$ \\
\hline $\begin{array}{l}\text { Body Mass Index - Wskaźnik masy ciała } \\
{\left[\mathrm{kg} / \mathrm{m}^{2} \text { ] }\right.}\end{array}$ & $21.4 \pm 3.2$ & $21.1 \pm 3.2$ & $21.3 \pm 3.2$ \\
\hline $\begin{array}{l}\text { Nutritional status - Stan odżywienia } \\
\text { Underweight - Niedowaga (\%) }\end{array}$ & 3.9 & 4.5 & 4.20 \\
\hline $\begin{array}{l}\text { Correct body weight - Prawidłowa masa } \\
\text { ciała [\%] }\end{array}$ & 75.5 & 77.7 & 76.6 \\
\hline Overweight - Nadwaga [\%] & 14.7 & 12.5 & 13.6 \\
\hline Obesity - Otyłość [\%] & 5.9 & 5.4 & 5.6 \\
\hline
\end{tabular}

on $=102,+q n=112, \sum n=214$.

The respondents provided information on the regularity of meals, having in-between meals, amount and type of fluid they drink and how often they eat selected foodstuffs. The consumption frequency was assessed with the use of score method; certain words were converted into points in the following manner: few times a day -7 points, once a day 6 points, four to six times a week -5 points, two to three times a week -4 points, once a week -3 points, one to three times a month -2 points, never -1 point.

Statistica software was used for statistical analysis of obtained data, the impact of gender on the dietary habits and choices was compared with the use test of difference between two rates of structure, while frequency of consuming selected foodstuffs, after excluding the normality of distribution with the Szapiro-Wilk test, was compared using the Mann-Whitney $U$ test.

\section{RESULTS}

The number of meals and their regularity was included in the nutrition assessment carried out in the said group of students. It has been observed that only $53.9 \%$ of respondents reported having recommended $4-5$ meals a day, the remaining respondents had not enough or too many meals, $11.6 \%$ of them had $1-2$ meals a day and $4.5 \%$ of respondents had more than five meals a day - Table 2. The statistical analysis showed that more girls than boys had insufficient number of meals, $1-2$ a day $(19.2 \%$ vs $2.1 \%, p \leq 0.05)$, while boys reported having recommended $4-5$ meals a day more often than girls $(62.1 \%$ vs $47.4 \%, p \leq 0.05)$. 
Table 2. Number of meals consumed daily by the surveyed youth Tabela 2. Liczba posiłków spożywanych codziennie przez badaną młodzież

\begin{tabular}{lccc}
\hline $\begin{array}{c}\text { The number of meals } \\
\text { Liczba posiłków }\end{array}$ & Boys - Chłopcy & Girls - Dziewczeta & Total - Razem \\
\hline $1-2^{*}$ & 2.1 & $\%$ & 11.6 \\
\hline 3 & 29.6 & 30.4 & 30.0 \\
\hline $4-5^{*}$ & 62.1 & 47.4 & 53.9 \\
\hline$\geq 6$ & 6.2 & 3.0 & 4.5 \\
\hline
\end{tabular}

In $=115$, o $n=136, \sum n=251$.

*Answers statistically significantly different between boys and girls; $p \leq 0.05$. - Odpowiedzi różnią się statystycznie istotnie pomiędzy chłopcami a dziewczętami; $p \leq 0,05$.

Almost half of surveyed boys and over $60 \%$ of surveyed girls did not have regular intervals between meals, in $10.4 \%$ of boys and $4.5 \%$ of girls were observed insufficient intervals (less than 3 hours) - Table 3. $27 \%$ of respondents reported sufficient intervals (3-4 hours) between meals. It has been observed that girls had their meals less regularly comparing to boys $(p \leq 0.05)$.

Table 3. Breaks between meals consumed by the surveyed youth Tabela 3. Przerwy pomiędzy posiłkami spożywanymi przez badaną młodzież

\begin{tabular}{lccc}
\hline \multirow{2}{*}{$\begin{array}{c}\text { Breaks between meals } \\
\text { Przerwy pomiędzy posiłkami }\end{array}$} & Boys - Chłopcy & Girls -Dziewczęta & Total - Razem \\
\cline { 2 - 4 } & & $\%$ & \\
\hline Irregularly * Nieregularnie & 49.6 & 63.9 & 57.3 \\
\hline Below 2 - Poniżej 2 h & 10.4 & 4.5 & 7.3 \\
\hline 3-4 h & 30.4 & 24.1 & 27.0 \\
\hline $4-6$ h & 7.8 & 6.0 & 6.9 \\
\hline Above 6 - Powyżej 6 h & 1.7 & 1.5 & 1.6 \\
\hline
\end{tabular}

ôn $=115$, o $n=136, \sum n=251$.

* Answers statistically significantly different between boys and girls; $p \leq 0.05$ - Odpowiedzi różnią się statystycznie istotnie pomiędzy chłopcami a dziewczętami; $p \leq 0,05$.

Almost all respondents reported having snacks between meals $(97.1 \%$ of girls and $99.1 \%$ of boys), their frequency was varying, one in four girl and one in three boy had snacks daily between meals - Table 4. The most frequently eaten snacks between meals were: fruits (76.4\%), sweets $(67.6 \%)$, sandwiches $(38 \%)$ as well as salty sticks and crisps $(22.4 \%)$. Boys had sandwiches between meals more often than girls $(54.8 \%$ vs $27.8 \%, p \leq 0.05)$ - Table 5 .

Table 4. The frequency of snacking between meals declared by the surveyed youth Tabela 4. Częstotliwość pojadania pomiędzy posiłkami deklarowana przez badaną młodzież

\begin{tabular}{lccc}
\hline \multirow{2}{*}{$\begin{array}{c}\text { Answer } \\
\text { Odpowiedź }\end{array}$} & Boys - Chłopcy & Girls - Dziewczęta & Total - Razem \\
\cline { 2 - 4 } & & $\%$ & \\
\hline Never - Nigdy & 0.9 & 2.9 & 2.00 \\
\hline Rarely - Rzadko & 22.8 & 27.2 & 25.2 \\
\hline Sometimes - Czasami & 42.1 & 44.9 & 43.6 \\
\hline $\begin{array}{l}\text { Often (daily) - Często } \\
\text { (codziennie) }\end{array}$ & 34.2 & 25.0 & 29.2 \\
\hline
\end{tabular}

ôn $=115$, o $n=136, \sum n=251$. 
Table 5. Type of foodstuff consumed between meals by the surveyed youth

Tabela 5. Rodzaj produktów pojadanych pomiędzy posiłkami przez badaną młodzież

\begin{tabular}{lccc}
\multicolumn{1}{c}{$\begin{array}{c}\text { Foodstuff } \\
\text { Produkt }\end{array}$} & Boys - Chłopcy & Girls - Dziewczęta & Total - Razem \\
\hline & & $\%$ & 76.4 \\
\hline Fruits - Owoce & 76.5 & 76.3 & 67.0 \\
\hline Sweets - Słodycze & 67.0 & 68.2 & 38.0 \\
\hline Sandwiches* - Kanapki & 54.8 & 27.8 & 22.4 \\
\hline $\begin{array}{l}\text { Breadsticks, crisps - Paluszki, } \\
\text { chipsy }\end{array}$ & 24.4 & 20.7 & 10.4 \\
\hline Fast-food & 13.9 & 7.4 & 7.6 \\
\hline Other - Inne & 10.4 & 5.2 & \\
\hline
\end{tabular}

In $=115$, o $n=136, \sum \mathrm{n}=251$.

* Answers statistically significantly different between boys and girls; $p \leq 0.05$ - Odpowiedzi różnią się statystycznie istotnie pomiędzy chłopcami a dziewczętami; $p \leq 0,05$.

Analysing the daily fluid consumption, one in five person drank less than 1 litre of fluids a day (girls were in the majority), $30 \%$ of respondents drank $1-1.5$ litres of beverages and $30 \%$ of respondents drank $1.5-2$ litres of beverages a day - Table 6 . Nearly $30 \%$ of surveyed boys reported drinking more than 2 litres a day.

Table 6 . The amount of fluid consumed daily by the surveyed youth Tabela 6. Ilość płynów wypijanych codziennie przez badaną młodzież

\begin{tabular}{lccc}
\hline \multicolumn{1}{c}{$\begin{array}{c}\text { The amount of fluid } \\
\text { llość płynów }\end{array}$} & Boys - Chłopcy & Girls - Dziewczęta & Total - Razem \\
\cline { 2 - 4 } & & $\%$ & \\
\hline Below 0.5 I - Poniżej 0.5 I & - & 3.7 & 2.0 \\
\hline $0.5-1$ I $^{*}$ & 8.0 & 26.9 & 18.2 \\
\hline $1-1.5$ I & 29.2 & 31.3 & 30.4 \\
\hline $1.5-2$ I & 34.5 & 26.9 & 30.4 \\
\hline Above 2 I* Powyżej 2 I & 28.3 & 11.9 & 19.0 \\
\hline
\end{tabular}

on $n=115$, $+n=136, \sum n=251$.

* Answers statistically significantly different between boys and girls; $p \leq 0.05$ - Odpowiedzi różnią się statystycznie istotnie pomiędzy chłopcami a dziewczętami; $p \leq 0,05$.

Over half of respondents mostly chose drinking water, one in four chose mostly soft drinks such as: fruit juice, fruit drink, Coke, and almost $18 \%$ of them drank mostly tea that was sweetened by $70 \%$ of respondents - Table 7,8 . More girls drank water comparing to boys $(60.3 \%$ vs. $47.5 \%, p \leq 0.05)$, boys were more likely to choose fruit juice and fruit drinks than girls $(p \leq 0.05)$.

Table 7. Type of drink usually drunk by the surveyed youth

Tabela 7. Rodzaj napoju pitego najczęściej przez badaną młodzież

\begin{tabular}{lccc}
\multicolumn{1}{c}{$\begin{array}{c}\text { Type of drink } \\
\text { Rodzaj napoju }\end{array}$} & Boys - Chłopcy & Girls - Dziewczęta & Total - Razem \\
\hline & & $\%$ & \\
\hline Water - Woda & 47.5 & 60.3 & 18.4 \\
\hline Tea - Herbata & 17.8 & 18.1 & 22.1 \\
\hline $\begin{array}{l}\text { Fruit juices, fruit drinks } \\
\text { Soki, napoje owocowe }\end{array}$ & 28.7 & 16.4 & 3.2 \\
\hline Cola drinks - Napoje typu cola & 4.0 & 2.6 & 2.3 \\
\hline Other - Inne & 2.0 & 2.6 & \\
\hline
\end{tabular}

on $=115$, o $n=136, \sum n=251$.

* Answers statistically significantly different between boys and girls; $p \leq 0.05$ - Odpowiedzi różnią się statystycznie istotnie pomiędzy chłopcami a dziewczętami; $p \leq 0,05$. 
Table 8. Sweetening tea by the surveyed youth

Tabela 8. Słodzenie herbaty przez badaną młodzież

\begin{tabular}{lccc}
\hline \multirow{2}{*}{$\begin{array}{c}\text { Answer } \\
\text { Odpowiedź }\end{array}$} & Boys - Chłopcy & Girls - Dziewczęta & Total - Razem \\
\cline { 2 - 4 } & & $\%$ & \\
\hline Yes $^{*}-$ Tak & 79.0 & 62.4 & 70.2 \\
\hline No* $^{*}$ Nie & 21.0 & 37.6 & 29.8 \\
\hline
\end{tabular}

ô $n=115$, o $n=136, \sum n=251$.

* Answers statistically significant differently between boys and girls; $p \leq 0.05$ - Odpowiedzi różnią się statystycznie istotnie pomiędzy chłopcami a dziewczętami; $p \leq 0,05$.

One in three respondent did not eat fruits every day and over $40 \%$ of them did not eat vegetables every day - Table 9,10 . The required daily amount of fruits was eaten by $31.9 \%$ of respondents and vegetables by $18.4 \%$ of respondents.

Table 9. The number of portions of fruits consumed daily by the surveyed youth Tabela 9. Liczba porcji owoców jadanych codziennie przez badaną młodzież

\begin{tabular}{lccc}
\hline \multicolumn{1}{c}{$\begin{array}{c}\text { Portions of fruits } \\
\text { Liczba porcji owoców }\end{array}$} & Boys - Chłopcy & Girls - Dziewczęta & Total - Razem \\
\cline { 2 - 4 } & & $(\%)$ & 33.1 \\
\hline $\begin{array}{l}\text { Do not always eat fruits every day } \\
\text { Nie zawsze codziennie }\end{array}$ & 29.2 & 36.3 & 29.4 \\
\hline 1 portion - 1 porcja & 32.7 & 26.7 & 31.9 \\
\hline 2-3 portions - 2-3 porcje & 31.0 & 32.6 & 5.7 \\
\hline Above 4 portions - Powyżej 4 porcji & 7.1 & 4.4 & \\
\hline
\end{tabular}

$n=115,+9 n=136, \sum n=251$.

Table 10. The number of portions of vegetables consumed daily by the surveyed youth Tabela 10. Liczba porcji warzyw jadanych codziennie przez badaną młodzież

\begin{tabular}{lccc}
\hline \multicolumn{1}{c}{$\begin{array}{c}\text { Portions of vegetables } \\
\text { Liczba porcji warzywa }\end{array}$} & Boys - Chłopcy & Girls - Dziewczęta & Total - Razem \\
\cline { 2 - 4 } & & $\%$ & 42.8 \\
\hline $\begin{array}{l}\text { Do not always eat vegetables every day } \\
\text { Nie zawsze codziennie warzywa }\end{array}$ & 39.5 & 45.6 & 34.0 \\
\hline 1 portion - 1 porcja & 36.0 & 32.4 & 18.4 \\
\hline 2-3 portions - 2-3 porcje & 19.3 & 17.7 & 4.8 \\
\hline Above 4 portions - Powyżej 4 porcji & 5.3 & 4.4 & \\
\hline
\end{tabular}

ôn $n=115,+9 n=136, \sum n=251$.

When analysing if gender affects the consumption of certain products, it was found that boys had significantly more often chosen white bread, confectionery, sugared breakfast cereals, sweetened yoghurts and kefir, cheese, fruit juice, fruit drinks, Coke-type drinks and energy drinks - Table 11,12,13. Moreover, the frequency of eating selected products depending on their cariogenic potential was compared. It has been observed that fruits were eaten more often than vegetables ( $p \leq 0.05$ ), white bread more often than "dark" bread $(p \leq 0.01)$, unsweetened yoghurts and kefir more often than sweetened ones ( $\leq \leq 0.05)$, fruit juices more often than vegetable juices $(p \leq 0.01)$. 
Table 11. The frequency of consumption of vegetables, fruits and selected carbohydrate foodstuffs; $\bar{x} \pm S D$ Tabela 11. Częstotliwość spożycia warzyw, owoców oraz produktów zbożowych; $\overline{\mathrm{x}} \pm \mathrm{SD}$

\begin{tabular}{|c|c|c|}
\hline Foodstuff type - Rodzaj produktu & Sex - Płeć & $\begin{array}{c}\text { Frequency - Częstotliwość } \\
\overline{\mathrm{X}} \pm \mathrm{SD}\end{array}$ \\
\hline \multirow{3}{*}{ Vegetables - Warzywa } & $\hat{\sigma}$ & $5.4 \pm 1.4$ \\
\hline & 우 & $5.5 \pm 1.3$ \\
\hline & $\Sigma$ & $5.5 \pm 1.3$ \\
\hline \multirow{3}{*}{ Fruits - Owoce } & $\hat{0}$ & $5.7 \pm 1.3$ \\
\hline & 우 & $5.8 \pm 1.2$ \\
\hline & $\Sigma$ & $5.8 \pm 1.2$ \\
\hline \multirow{3}{*}{$\begin{array}{l}\text { White bread (buns, mixed bread, toasted bread) }{ }^{\star *} \\
\text { Pieczywo jasne (bułki, chleb mieszany, pieczywo } \\
\text { tostowe) }\end{array}$} & $\overline{0}$ & $6.1 \pm 1.2$ \\
\hline & q & $5.2 \pm 2.0$ \\
\hline & $\Sigma$ & $5.6 \pm 1.7$ \\
\hline \multirow{3}{*}{$\begin{array}{l}\text { "Dark" bread (graham, whole grains, wholemeal) } \\
\text { Pieczywo ciemne (graham, pełnoziarniste, razowe) }\end{array}$} & $\hat{0}$ & $4.2 \pm 2.0$ \\
\hline & P & $4.7 \pm 1.9$ \\
\hline & $\Sigma$ & $4.5 \pm 2.0$ \\
\hline \multirow{3}{*}{$\begin{array}{l}\text { Confectionary (donuts, pastries, cakes) } \\
\text { Pieczywo cukiernicze (pączki, drożdżówki, ciasta) }\end{array}$} & $0^{\pi}$ & $3.8 \pm 1.6$ \\
\hline & q & $3.1 \pm 1.3$ \\
\hline & $\Sigma$ & $3.4 \pm 1.5$ \\
\hline \multirow{3}{*}{ Unsweetened cereal - Płatki zbożowe niesłodkie } & $\pi$ & $3.0 \pm 1.8$ \\
\hline & 우 & $2.7 \pm 1.8$ \\
\hline & $\Sigma$ & $2.8 \pm 1.8$ \\
\hline \multirow{3}{*}{ Sweetened cereal ${ }^{*}$ - Płatki zbożowe słodkie } & 0 & $3.3 \pm 1.9$ \\
\hline & 운 & $2.8 \pm 1.8$ \\
\hline & $\Sigma$ & $3.0 \pm 1.9$ \\
\hline \multirow{3}{*}{ Sweets - Słodycze } & $0^{\pi}$ & $4.2 \pm 1.6$ \\
\hline & q & $4.3 \pm 1.6$ \\
\hline & $\Sigma$ & $4.3 \pm 1.6$ \\
\hline
\end{tabular}

on $n=102,+q n=112, \sum n=214$.

${ }^{*}{ }^{* *}$ Frequency of consumption of the foodstuffs dependent on sex - Częstotliwość spożycia produktu różna, zależna od płci, ${ }^{*} p \leq 0.05,{ }^{* *} p \leq 0.01$.

\# - Statistically significantly difference in the frequency of consumption of marked foodstuffs - Statystycznie istotna różnica w częstotliwości spożycia oznaczonych produktów, $p \leq 0,05$.

Table 12. Frequency of consumption of selected dairy foodstuffs; $\overline{\mathrm{x}} \pm \mathrm{SD}$

Tabela 12. Częstotliwość spożycia wybranych produktów nabiałowych; $\overline{\mathrm{x}} \pm \mathrm{SD}$

\begin{tabular}{|c|c|c|}
\hline Foodstuff type - Rodzaj produktu & Sex - Płeć & $\begin{array}{c}\text { Frequency - Częstotliwość } \\
\overline{\mathrm{X}} \pm \mathrm{SD}\end{array}$ \\
\hline \multirow{3}{*}{ Dairy foodstuffs overall - Nabiał ogółem } & $\hat{\sigma}$ & $5.7 \pm 1.4$ \\
\hline & q & $5.5 \pm 1.9$ \\
\hline & $\Sigma$ & $5.6 \pm 1.4$ \\
\hline \multirow{3}{*}{ Cheese $^{* *}-$ Żółte sery } & $0^{1}$ & $5.2 \pm 1.6$ \\
\hline & P & $4.6 \pm 1.8$ \\
\hline & $\Sigma$ & $4.9 \pm 1.7$ \\
\hline \multirow{3}{*}{$\begin{array}{l}\text { Unsweetened yoghurt, kefir } \\
\text { Jogurty, kefiry naturalne }\end{array}$} & $\hat{\sigma}$ & $3.9 \pm 1.9$ \\
\hline & q & $3.9 \pm 1.9$ \\
\hline & $\Sigma$ & $3.9 \pm 1.9$ \\
\hline \multirow{3}{*}{$\begin{array}{l}\text { Sweetened yoghurt, kefir ** } \\
\text { Jogurty kefiry słodkie }\end{array}$} & $\pi$ & $3.9 \pm 1.9$ \\
\hline & o & $3.2 \pm 1.8$ \\
\hline & $\Sigma$ & $3.5 \pm 1.9$ \\
\hline
\end{tabular}

In $=102$, o $n=112, \sum n=214$.

Explanations see Table 11 - Objaśnienia zob. tab. 11. 
Table 13. Frequency of consumption of selected drinks; $\overline{\mathrm{x}} \pm \mathrm{SD}$

Tabela 13. Częstotliwość spożycia wybranych napojów; $\overline{\mathrm{x}} \pm \mathrm{SD}$

\begin{tabular}{|c|c|c|}
\hline Foodstuff type - Rodzaj produktu & Sex-Płeć & $\begin{array}{c}\text { Frequency - Częstotliwość } \\
\overline{\mathrm{X}} \pm \mathrm{SD}\end{array}$ \\
\hline \multirow{3}{*}{ Water - Woda } & $0^{\pi}$ & $6.5 \pm 1.3$ \\
\hline & 우 & $6.6 \pm 1.1$ \\
\hline & $\Sigma$ & $6.7 \pm 1.2$ \\
\hline \multirow{3}{*}{ Juice fruit * - Soki owocowe } & $0^{\pi}$ & $4.6 \pm 1.8$ \\
\hline & 우 & $4.1 \pm 1.7$ \\
\hline & $\Sigma$ & $4.4 \pm 1.8$ \\
\hline \multirow{3}{*}{ Vegetable juices - Soki warzywne } & $0^{\lambda}$ & $2.5 \pm 2.0$ \\
\hline & q & $2.1 \pm 1.6$ \\
\hline & $\Sigma$ & $2.3 \pm 1.8$ \\
\hline \multirow{3}{*}{ Fruit drinks ${ }^{* \star}$ - Napoje owocowe } & $0^{\lambda}$ & $4.9 \pm 1.7$ \\
\hline & 우 & $4.1 \pm 1.9$ \\
\hline & $\Sigma$ & $4.5 \pm 1.8$ \\
\hline \multirow{3}{*}{ Cola drinks ${ }^{* *}$ - Napoje typu cola } & $0^{\lambda}$ & $3.7 \pm 1.7$ \\
\hline & q & $3.0 \pm 1.7$ \\
\hline & $\Sigma$ & $3.3 \pm 1.7$ \\
\hline \multirow{3}{*}{$\begin{array}{l}\text { Energy drinks** } \\
\text { Napoje energetyzujące }\end{array}$} & $0^{\pi}$ & $2.7 \pm 1.8$ \\
\hline & q & $2.0 \pm 1.6$ \\
\hline & $\Sigma$ & $2.4 \pm 1.7$ \\
\hline
\end{tabular}

ôn $=102$, $, \mathrm{n}=112, \sum \mathrm{n}=214$.

Explanations see Table 11 - Objaśnienia zob. tab. 11.

\section{DISCUSSION}

There are several factors causing dental and periodontal diseases. A significant impact in that respect have such dietary habits as: having regular meals and frequency of in-between meals (Marshall 2009). It is recommended to have 4-5 meals a day, preferably at constant hours and to avoid having in-between meals. In group of $64.5 \%$ of respondents meals were not at regular times and intervals between them were inadequate. Also study carried out by Goluch-Koniuszy (2010), Kolarzyk et al. (2010) and Ziółkowska et al. (2010) confirm that young people have irregular mealtimes. It is alarming that young people believe that having meals at regular times is insignificant for health status and maintaining a healthy weight (Wojtyła et al. 2011). Adequate intervals between meals are significant for self-cleansing process in the mouth when saliva rinses teeth and food particles are washed out. Saliva contains proline-rich proteins (they promote enamel remineralisation), mucins (glycoproteins protecting enamel against physical damage), antimicrobial agents (lactoferrin, lysozyme, IgA and IgG immunoglobulins) and buffer system (bicarbonates that control $\mathrm{pH}$ level in the mouth) (Sierpińska et al. 2008). Among other things, the activity of salivary glands depends on the level of hydration in the body. Analysing the obtained results, it may be stated that one in five respondent drank less that 1 litre of fluids a day what may cause inadequate body hydration and poor salivary secretion. 
Irregular mealtimes aids having in-between meals. $29.2 \%$ of respondents reported having in-between meals every day. They usually had fruits but also high-calorie products such as: sweets, sandwiches, snacks in form of crisps and salty sticks. Such products do not provide an organism with sufficient nutrients, they have high energetic value but not nutrition one. They often replace meals rich in nutrients that are valuable for human health. Sugars derived from such products are converted by bacteria to acids, mainly lactic acid, causing demineralisation of enamel by decreasing $\mathrm{pH}$ in the mouth. It is significant for dental health, particularly for young people attending school who do not have chance to brush teeth and neutralise $\mathrm{pH}$ by using mouthwash (Malepszy et al. 2000). Foodstuff and soft drinks with high sugar content have the most detrimental effect when they are eaten between meals (Szczepańska et al. 2008). Moreover, the residence time of food in the mouth is of vital importance. The higher viscosity of food (crisps, candies) as well as the longer residence time in the mouth are, the higher risk of developing dental caries is (Pawka et al. 2010). The study results showed that $98 \%$ of young people eat various snacks between main meals. Similar results were obtained by Wierzbicka and Roszkowski (2005) and Urbańska and Czarniecka-Skubina (2007).

The said group of young people reported having sweets very often. Almost half of them had sweets at least few times a week. The study conducted by Komosińska et al. (2001) showed that almost half of young people consumed sweets at least twice a day and similarly to the studies carried out by the author, the frequency of their consumption was not associated with gender. A high intake of sugars derived from foodstuffs and beverages decreases rapidly $\mathrm{pH}$ of dental plague, which subsequently starts enamel erosion and monosaccharides are the best medium for cariogenic bacteria to perform fermentation. Due to demineralisation of inorganic substance and proteolysis of organic substance, acids formed by bacteria cause caries formation in dentition and bacteria developing in dental plague may lead to severe systemic complications (Suematsu et al. 2016).

The problem associated with significant consumption of sweets and fast food by young people is that nutritious foodstuffs (milk and dairy products, wholegrain cereals, pulses, fruits and vegetables) in daily menu being a valuable source of vitamins and minerals essential to growth and development are replaced with sweets and fast food.

Moreover, fruit juices and sweetened soft drinks having cariogenic potential were preferred choices of one in four respondent. Sweetened soft drinks of Coke-type have severe erosive properties, their long-term and frequent consumption causes so-called acid enamel erosion. Eroded tooth structure is susceptible to development of dental caries. It has been also confirmed that $\mathrm{pH}$ of many fruit juices, fresh fruits and Coke-type soft drinks ranges from 2.1-4.5, it is below the critical $\mathrm{pH}(\mathrm{pH}<5.5)$ (Jensdottir et al. 2006). Consumption of carbonated soft drinks increases significantly the risk of developing dental caries ( $O$ 'Sullivan and Curzon 2000). Thanks to buffer agents in saliva the $\mathrm{pH}$ level is neutralised in about 30 minutes. Frequent consumption of foodstuffs with acid $\mathrm{pH}$ level impedes reaching relevant acidity in the mouth, exacerbates enamel demineralisation and hampers enamel remineralisation (Spolsky et al. 2007). 
When analysing the frequency of consuming selected foddstuffs, it has been found that young people made a significant mistake as they had fruits more often than vegetables, chose bread with low diet fibre and drank fruit juices more often than vegetable ones. Consuming low-processed foodstuffs such as wholegrain goods and cereals exerts a positive impact on teeth (Wysocka 2012). They are the source of complex carbohydrates, vitamins, minerals and dietary fiber that increases the food volume and removes dental plague mechanically (Olczak-Kowalczyk and Kowalczyk 2010; Olczak-Kowalczyk et al. 2015). Moreover, biting and chewing whole-grain bread increases saliva secretion and promotes self-cleansing process in the mouth.

It is worth emphasizing that young people often consume dairy products being a significant source of calcium, which in turns has a positive impact on the dentition development and dental health. Milk proteins acting locally on teeth tissue, decrease dentine sensitivity to acids. Głąbska et al. (2007) observed a positive impact of eating rennet cheese on the level of caries detection index. Having rennet cheese after meal containing sugar, accelerates significantly stabilisation of $\mathrm{pH}$ in the mouth. Additionally, so-called hard cheese stimulates saliva secretion and it acts like buffer what promotes self-cleansing in the mouth. Milk is also a source of magnesium and potassium (base-forming elements), phosphates, lipids, casein phosphopeptides - stabilising calcium and phosphate ions in the mouth and the facilitate intestinal absorption of calcium, iron and zinc (Tanaka et al. 2010).

\section{CONCLUSIONS}

The obtained results show that dietary habits and choices that promote the development of dental caries are frequent among young people under study. They are as follows: meals are not regular, they often have in-between meals, they eat sweets and sweetened products as well as they drink sweetened soft drinks.

Girls were characterized by less correct nutritional habits compared to boys, rarely ate the recommended amount of food, ate less regularly, drank less amount of fluids. While boys made worse dietary choices: they rarely than girls ate wholemeal bread, more often chose sweet cereal flakes, sweet yogurt and kefir and more often drink sweet drinks.

Taking into account the observed irregularities i.e. numerous dietary mistakes affecting increased cariogenic diet potential, young children attending school should be especially careful to take care of oral hygiene and correct their dietary habits. Additionally, dentists and dieticians should pay attention to the significance of good dietary habits in preventing dental caries and encourage their patients to correct their dietary habits that exacerbate dentition and periodontium diseases.

\section{REFERENCES}

Bagińska J., Stokowska W. 2006. Nawyki żywieniowe a intensywność próchnicy wczesnej u małych dzieci [Nutritional habits and early caries intensity in young children]. Wiad. Lek. 59(1-2), 5-9. [in Polish]

Ganowicz M., Wierzbicka M., Pierzynowska E., Zawadziński M., Jodkowska E. 2007. Występowanie próchnicy u dzieci w wieku 6 lat w Polsce w 2005 roku [Caries prevalence in 6 year-old children in Poland in 2005]. Nowa Stomatol. 1, 3-7. [in Polish] 
Głąbska D., Sińska B., Remiszewski A. 2007. Analiza zależności między spożyciem mleka i produktów mlecznych a zmianami próchnicowymi u dzieci i młodzieży [Analysis of the dependence between milk and dairy products consumption, and dental caries observed in group of children and teenagers]. Rocz. Panstw. Zakł. Hig. 58(1), 69-75. [in Polish]

Goluch-Koniuszy Z. 2010. Ocena sposobu żywienia dzieci w okresie skoku pokwitaniowego z BMI $\leq 5$ percentyla $z$ terenu miasta Szczecin [Evaluation of the nutrition mode in children during the pubertal period with $\mathrm{BMI} \leq 5$ percentile in the city of Szczecin]. Rocz. Panstw. Zakł. Hig. 61(3), 307-315. [in Polish]

Hilt A., Rybarczyk-Townsend E., Wochna-Sobańska M. 2014. Stan uzębienia uczniów szkół gimnazjalnych województwa łódzkiego [Dentition status in middle schools students in the Lodzkie Province]. Prz. Epidemiol. 68, 143-146. [in Polish]

Jensdottir T., Holbrook P., Nauntofte B., Buchwald C., Bardow A. 2006. Immediate erosive potential of cola drinks and orange juices. J. Dent. Res. 85(3), 226-230.

Kolarzyk E., Młynarska-Lang D. 2010. Zwyczaje żywieniowe młodzieży krakowskich szkół gimnazjalnych i ponadgimnazjalnych [Nutritional habits of high school students in Kracow]. Probl. Hig. Epidemiol. 91(3), 414-418. [in Polish]

Komosińska K., Woynarowska B., Mazur J. 2001. Zachowania zdrowotne związane z żywieniem u młodzieży szkolnej w Polsce w latach 1990-1998 [Nutritional health behaviors of schoolchildren in Poland in 1990-1998]. Żyw. Człow. Metab. 28(1), 17-30. [in Polish]

Law V., Seow W.K., Townsend G. 2007. Factors influencing oral colonization of mutans streptococci in young children. Aust. Dent. J. 52(2), 93-100.

Malepszy A., Nowak-Malinowska H., Kaczmarek U. 2000. Wybrane parametry stanu zdrowia narządu żucia 18-letniej młodzieży z województwa dolnośląskiego [Selected parameters of the state of health of chewing organs of 18-year-old youth from the Lower Silesian Voivodship]. Wroc. Stomatol. 104-109. [in Polish]

Marshall T.A. 2009. Chairside diet assessment of caries risk. J. Am. Dent. Assoc. 140(6), 670-674.

Moynihan P., Petersen P.E. 2004. Diet, nutrition and the prevention of dental diseases. Public. Health Nutr. 7(1A), 201-226.

O'Sullivan E.A., Curzon M.E. 2000. A comparison of acidic dietary factors in children with and without dental erosion. ASDS J. Dent. Child. 67(3), 186-192.

Olczak-Kowalczyk D., Jackowska T., Czerwonka-Szaflarska M., Książyk J., Szostak-Węgierek D., Kaczmarek U. 2015. Stanowisko polskich ekspertów dotyczące zasad żywienia dzieci i młodzieży $\mathrm{w}$ aspekcie zapobiegania chorobie próchnicowej [Guidelines of Polish experts regarding the nutrition rules of children and adolescents in the aspect of dental caries prevention]. Nowa Stomatol. 20(2), 81-91. [in Polish]

Olczak-Kowalczyk D., Kowalczyk W. 2010. Odżywianie a zdrowie jamy ustnej dzieci [Nutrition and oral heath in children]. Mag. Stomatol. 20(6), 48-56. [in Polish]

Pawka B., Dreher P., Herda J., Szwiec I., Krasicka M. 2010. Próchnica zębów u dzieci problemem społecznym [Dental caries in children as a social problem]. Probl. Hig. Epidemiol. 91(1), 5-7. [in Polish]

Różdżyńska-Świątkowska A., Kułaga Z., Grajda A., Gurzkowska B., Góźdź M., Wojtyło M., Świąder A., Litwin M. 2013. Wartości referencyjne wysokości, masy ciała i wskaźnika masy ciała dla oceny wzrastania i stanu odżywienia dzieci i młodzieży w wieku 3-18 lat [Height, weight and body mass index references for growth and nutritional status assessment in children and adolescents 3-18 year of age]. Stand. Med. Pediatr. 1,11-21. [in Polish]

Sierpińska T., Stocka A., Gołębiewska M. 2008. Struktura szkliwa, właściwości śliny oraz bruksizm jako czynniki etiologiczne odpowiedzialne za starcie patologiczne. Przegląd piśmiennictwa [Enamel structure, saliva and bruxism as aetiological factors responsible for pathological tooth wear. A literature review]. Protet. Stomatol. 58(2),100-104. [in Polish]

Spolsky V.W., Black B.P., Jenson L. 2007. Products - old, new, and emerging. J. Calif. Dent. Assoc. 35(10), 724-737. 
Strużycka I., Wierzbicka M., Jodkowska E., Rusyan E., Ganowicz M., Niemiecka K. 2013. Wyniki Monitoringu Stanu Zdrowia Jamy Ustnej populacji młodych dorosłych w Polsce w 2012 roku [Results of nation wide epidemiological surveys of oral health in young adults in Poland in 2012]. Nowa Stomatol. 4, 195-199. [in Polish]

Suematsu Y., Miura S., Zhang B., Uehara Y., Ogawa M., Yonemoto N., Nonogi H., Nagao K., Kimura T., Saku K. 2016. Association between dental caries and out-of-hospital cardiac arrests of cardiac origin in Japan. J. Cardiol. 67(4), 384-391.

Szczepańska J., Lubowiedzka-Gontarek B., Pawłowska E., Szydłowska-Walendowska B. 2008. Czynniki ryzyka próchnicy związane z żywieniem a liczebność bakterii próchnicotwórczych w ślinie dzieci w wieku 3 lat [Caries risk factors related to nutrition and salivary levels of cariogenic bacteria in children in the age of 3 years]. Dent. Med. Probl. 45(2), 156-164. [in Polish]

Tanaka K., Miyake Y., Sasaki S. 2010. Intake of dairy products and the prevalence of dental caries in young children. J. Dent. 38(7), 579-583.

Turska-Szybka A., Soika I., Kalita M., Gozdowski D., Olczak-Kowalczyk D. 2016. Stan uzębienia uczniów szkół gimnazjalnych na podstawie Monitoringu Stanu Zdrowia Jamy Ustnej i Jego Uwarunkowań w 2015 roku w województwie mazowieckim. Część I. Choroba próchnicowa [Dentition in children attending secondary school based on 2015 Monitoring of Oral Health and its Determinants in Mazovia Province. Part I. Dental caries]. Nowa Stomatol. 3, 181-192. DOI: 10.5604/14266911.1221195. [in Polish]

Urbańska l., Czarniecka-Skubina E. 2007. Częstotliwość spożycia przez młodzież produktów spożywczych oferowanych w sklepikach szkolnych [Food products consumption frequency of youth offered by school shops]. Żywn. Nauka Technol. Jakość 3(52), 193-204. [in Polish]

Vacca Smith A.M., Scott-Anne K.M., Whelehan M.T., Berkowitz R.J., Feng C., Bowen W.H. 2007. Salivary glucosyltransferase B as a possible marker for caries activity. Caries Res. 41(6), 445-450.

Wierzbicka E., Roszkowski W. 2005. Ocena spożycia żywności z uwzględnieniem produktów typu fast ford w wybranej grupie młodzieży [Analysis of food intake, including fast-food meals, by a group of adolescents]. Bromat Chem Toksykol 38(Supl), 561-566. [in Polish]

Wojtyła A., Biliński P., Bojar I., Wojtyła C. 2011. Zaburzenia odżywiania u polskich gimnazjalistów [Eating disorders among Polish adolescents attending junior high schools]. Probl. Hig. Epidemiol. 92(2), 343-350. [in Polish]

Wysocka M. 2012. Wpływ założenia stałego aparatu ortodontycznego na nawyki żywieniowe młodzieży i młodych dorosłych [Effect of setting up a fixed orthodontic device on eating habits of adolescents and young adults]. PhD thesis. Poznań, AM (typescript). [in Polish]

Ziółkowska A., Gajewska M., Szostak-Węgierek D. 2010. Zachowania żywieniowe młodzieży gimnazjalnej z Warszawy i miejscowości podwarszawskich [Nutritional habits of secondary school students from Warsaw and the Warsaw vicinity]. Probl. Hig. Epidemiol. 91(4), 606-610. [in Polish]

Abstract. Correct eating habits have a significant impact on the condition of teeth and periodontal. The aim of the study was to evaluate the cariogenicity of the diet in a select group of young people aged 15-16 years old. The survey was conducted in June 2016 among 251 students attending middle schools in Szczecin (115 boys and 136 girls). The survey consisted of completing an anonymous questionnaire about eating habits and food intake that affect the formation of dental caries. The obtained results indicate a frequent occurrence among the young people of behaviors and food choices that contribute to the development of dental caries. These included the lack of regularity in eating meals (declared by $57.3 \%$ of respondents), frequent snacking between meals (declared by $72.8 \%$ of students), frequent eating sweets and sweetened products and drinking sweet beverages. Girls were characterized by less correct nutritional habits compared to boys, rarely ate the recommended amount of food, ate less regularly, drank less amount of fluids. While boys made worse dietary choices: they rarely than girls ate wholemeal bread, more often chose sweet cereal flakes, sweet yogurt and kefir and more often drink sweet drinks. Taking into account the observed irregularities, consisting of 
a significant number of improper eating behaviors affecting the cariogenicity of the diet, schoolchildren should be especially careful to take care of oral hygiene and participate in nutrition education. Additionally, dentists and dieticians should pay attention to the significance of good dietary habits in preventing dental caries and encourage their patients to correct their dietary habits that exacerbate dentition and periodontium diseases. 
